act H. 3. 2. 17. 1)

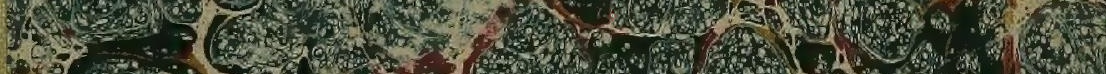

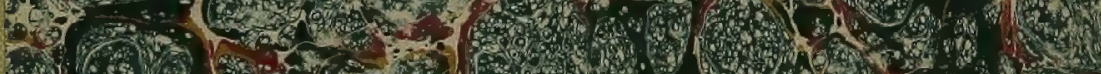
(1) ( we -

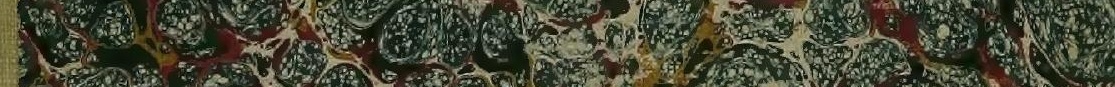

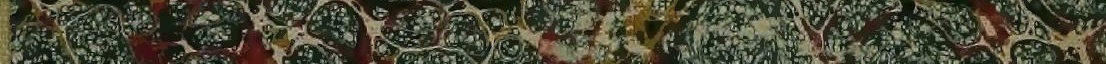

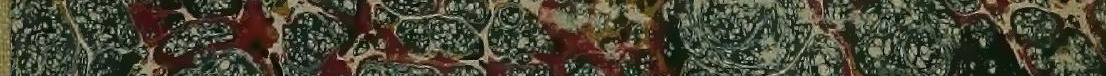
(1)

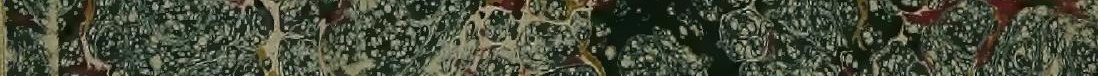

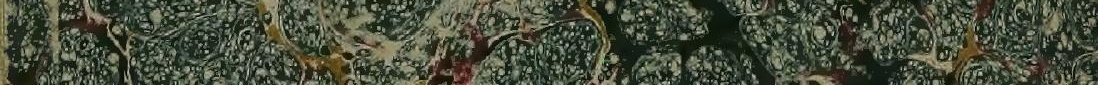
9.

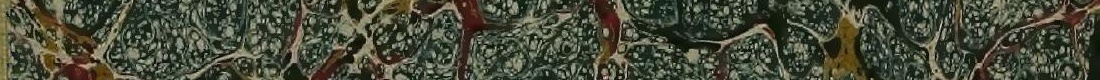

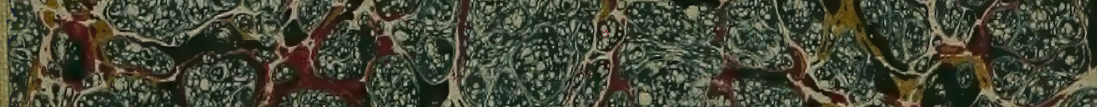

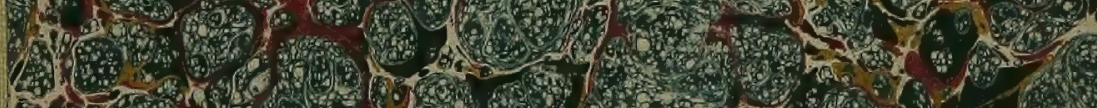

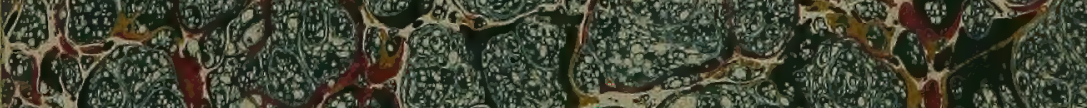

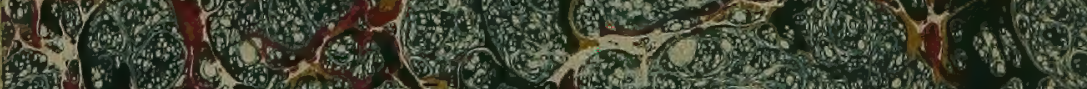

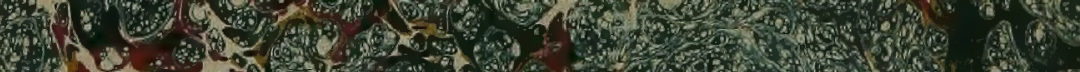

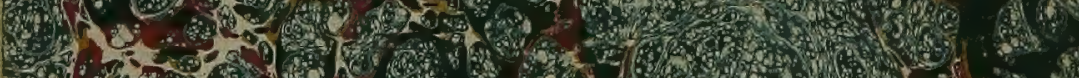

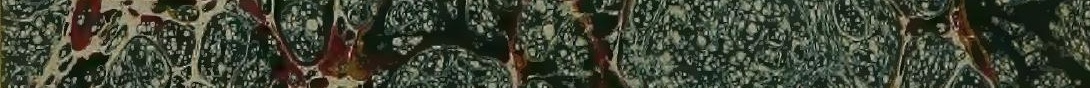
-

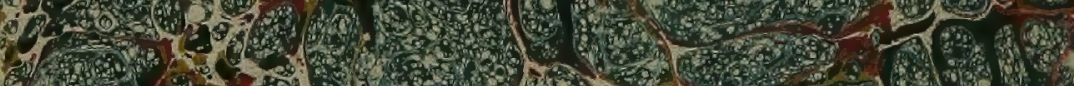

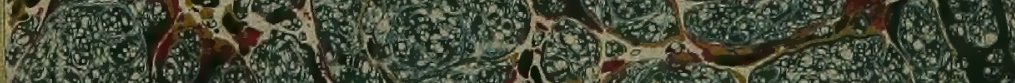
(6.).

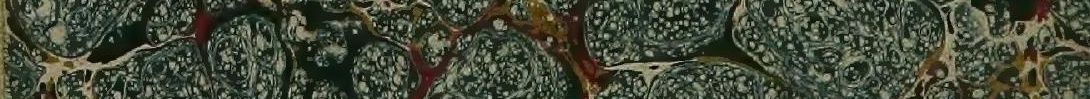
258 (1)

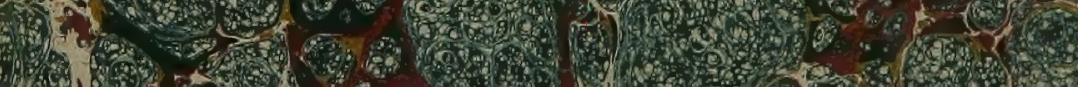

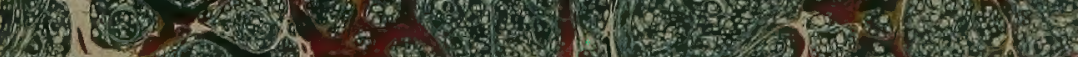




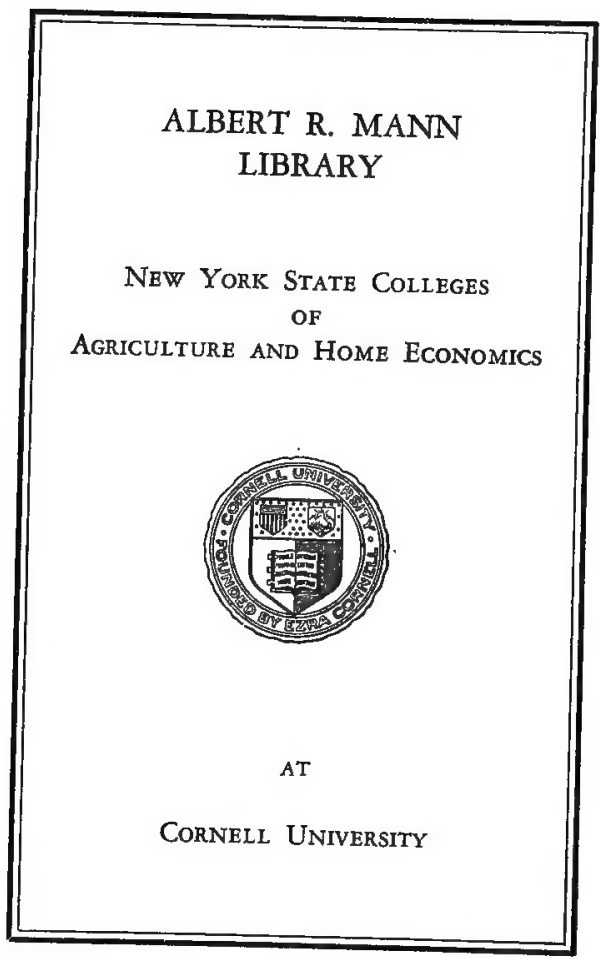




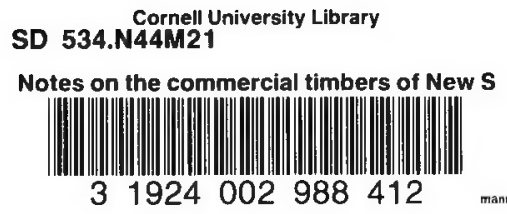




\section{Cornell University Library}

The original of this book is in the Cornell University Library.

There are no known copyright restrictions in the United States on the use of the text.

http://www.archive.org/details/cu31924002988412 
Issued under the Authority of the Minister for Mines and Agriculture.

\author{
NOTES \\ ox this \\ COMMERCIAL TIMBERS \\ OF: \\ NEW SOUTH WALES; \\ $\mathrm{BY}$ \\ J. H. MAIDEN, F.L.S., \&C., \\ CONSLLTING BOTANIST TO THE DEPARTMEX TS OF AGRICLITUKE AND FORESTS.
}

SYDNEY: CHARLES POTTER, GOVERNMENT PRINTER; PHLLLIP STREET. 

Issued under the Authority of the Minister for Mines and Agriculture.

\section{NOTES}

ON THE

\section{COMMERCIAL TIMBERS}

OF

\section{NEW SOUTH WALES;}

BY

J. H. MAIDEN, F.L.S., \&C.,

CONSULTING BOTANIST TO THE DEPARTMENTS OF AGRICULTURE AND FORESTS.

SYDNEY : CHARLES POTTER, GOVERNMENT PRINTER, PHILLIP STREET. 1898. 



\section{TABLE OF CONTENTS.}

PAGE.

$\begin{array}{llllllllll}\text { INTRODUCTORY } & \ldots & \ldots & \ldots & \ldots & \ldots & \ldots & \ldots & \ldots & 1\end{array}$

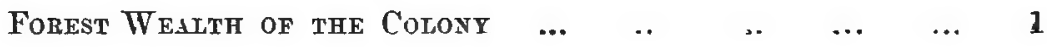

$\begin{array}{lllllllllll}\text { TIMBERS FOR } & \text { EXPORT } & \ldots & \ldots & \ldots & \ldots & \ldots & \ldots & \ldots & 2\end{array}$

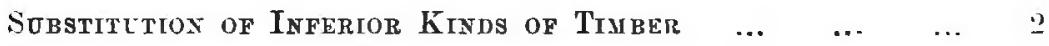

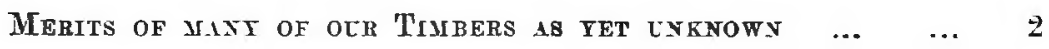

Stpply of Seasoned Colonil Timbers true to mame $\quad . . . \quad 3$

$\begin{array}{lllllllllll}\text { Seasonimg Processers } & \ldots & \ldots & \ldots & \ldots & \ldots & \ldots & \ldots & 4\end{array}$

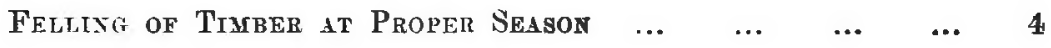

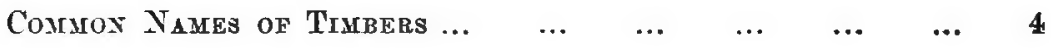

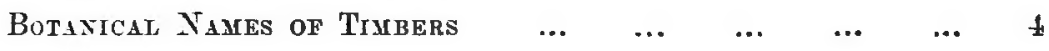

Crassiffcation and Description of odr Commerciad Tmaers... 6

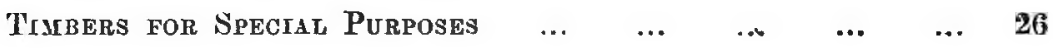

$\begin{array}{lllllllllll}\operatorname{IxDEx} & \ldots & \ldots & \ldots & \ldots & \ldots & \ldots & \ldots & \ldots & \ldots & 31\end{array}$ 



\title{
Notes on the Commercial Timbers of New South Wales.
}

\author{
By J. H. MAIDEN, \\ Consulting Botanist.
}

\section{Introductory.}

Tur object of this pamphlet is to give information in regard to the principal commereial timbers of New South Wales, in language as devoid as possible of scientific technicalities.

Only those points are touched upon that are of practical moment to the timber-getter, saw-miller, merchant, or user.

I have endeavoured to give an impartial statement of the merits of our timbers as we know them in 1895. In course of time some of the estimates of the qualities of particular timbers may require to be modified, and other timbers, not at present employed, may be shown to be useful for special purposes. If $I$ have erred in my estimate of the usefulness of a partioular timber, I shall be glad to be set right.

For the last fourteen years I have been almost daily occupied in the diagnosis and critical examination of colonial timbers of all kinds; I have been a large user of many kinds of colonial timbers for miscellaneous purposes, and I have visited most of the principal forests and saw-mills of this Colony.

\section{Forest Wealth of the Colony.}

I have no desire to use the language of exaggeration, but I can safely say that New South Wales is one of the most richly-endowed countries in the world as regards its forest wealth. I should be sorry to say that our timber supplies are unlimited, far from it, but with our small population we have immense areas of practically virgin forest, and in many places, as the trees are cut out, numbers of young trees are coming forward, and flourish without hindrance, thus ensuring the stability of our timber supply.

With few exceptions, most of our trees require no artificial replanting; what is simply required is conservation-protection of the young growth from damage by animals, fires, \&c., and, in certain cases, what is called "thinning," which consists in destroying or weeding out sickly, malformed, or overcrowded saplings.

Most of our valuable timbers are found in the coast and coast mountain districts. A few, e.g., the cypress pines of the western districts, and the ironbark of Dubbo (and thence to the north-east), are found in the drier parts of the Colony. 


\section{Timbers for Export.}

As regards the export trade, as the merits of our hard woods become more fully realised, a largely increased demand may reasonably be expected to set in for them. Our soft pine can probably be largely utilised for butterboxes. Our figured brush timbers have to win their way to recognition in the world's markets. This will necessarily be slow, but we have much valuable evidence as to their merits to encourage us to make them more widely known.

May I, at this place, insist that timbers of a kind should be kept together in wood-paving? No two timbers are of such similar texture in all respects that they wear absolutely equally wheri formed into a roadway. A road engineer would never dream of laying together stone cubes of various materials. The irregularity in wear of a wooden roadway is especially detrimental, and I desire to raise my voice against the pernicious doctrine that our timbers may be mixed in the same stretch of roadway. There is no excuse for mixing them, as they can be readily separated by any man who has devoted some attention to the subject, and timbers not of the first class would stand a better chance of useful employment if they formed strips of roadway by themselves.

\section{Substitution of inferior kinds of Timber.}

Too great care cannot be exercised in seeing that timber which is sent to market, and particularly that intended for export, is not only good of its kind, but also belongs to a species of acknowledged merit. In the case of trees or timbers which bear a resemblance more or less strong to valuable timbers, the greatest care should be exercised. Let no messmate, swamp, white, cabbage, ribbon, or apple gums be sent forward, no matter how well they may look, for such timber as these, which decay readily, bring our timbers and the whole Colony into disrepute. Some of our good timbers are addmittedly difficult to diagnose, particularly to the European buyer, and just as they are winning their way to recognition on their own merits, it is a cruel thing for careless or unprincipled suppliers to injure the trade. The promises held out as to the merits of our timbers are very carefully inquired into in Europe, and the successful substitution of inferior timber can only be temporary. To those of our millers who are situated near forests of our best timbers it may seem ludicrous to issue a warning about swamp gum, for instance, but many cases of the substitution, in this and other colonies, of the most inferior timbers have come under my personal notice. The system of Government inspection of timbers for export, recently inaugurated, may be valuable in creating confidence amongst buyers, but such a system, to be efficacious, should be compulsory in regard to all shipments, at all events for a short term of years, by which time buyers might be expected to be conversant with our timbers.

\section{Merits of many of our Timbers as yet unlnnown.}

So few of our brush and other timbers have been tested by experts as regards their merits for special uses, e.g., carving, wood-engraving (see "Timbers for special purposes," page 26), that we are not yet in a position to speals definitely in regard to them. The circumstances of a new country have caused our timbers to be examined rather as materials of construction, and so it is that we are far more fully informed as to their merits for engineering and architectural works than as regards their less important, (though not to be despised) minor uses. 
A number of our timbers are, however, being tested as regards their suitability for wood-carving, and there is reason to suppose that we possess a fair number of timbers useful for this purpose. My own feeling is one of regret that the art of wood-carving has been so neglected in this Colony, as it is a useful art, and, as time rolls on, a considerable amount of employment will be available, both to men and women carrers of decorative work, for fittings of buildings, furniture, \&c., to say nothing of more purely art objects for the decoration of the home, \&c. And not only will wood-carving prove a remunerative occupation for many people, and a useful accomplishment for persons of leisure, but it will be the means of drawing public attention to the texture and properties of our natire timbers, and of utilising some of those which at the present time are put to no particular purpose.

\section{Supply of seasoned Colonial Timbers, true to name.}

As a consistent advocate for many years of the use of colonial timbers, I have become familiar with the oft-repeated objection, "What is the good of adrocating the use of colonial timbers when we rarely can buy any already seasoned?" It is a fact that very few varieties of seasoned colonial timbers are kept in stock by our timber merchants. Timber merchants are like other tradesmen in endeavouring to keep a stock of any article that may sell, but we cannot expect them to run their business on sentiment; in other words, to convert their timber-yards into sample museums. Consequently, in the first. place, we require to educate our own people in regard to the merits of our timbers, and then they will endeavour to use more of them. I think that, as regards the general public, a certain amount of sentiment would not be out of place in endearouring to encourage the use of colonial timbers. I mean that, having satisfied himself that a certain colonial timber is suitable for a certain purpose, the Australian citizen might well put himself to a little trouble to cause bis mant to be supplied. These new timbers of a new country have to work their way to public recognition, and it is often far easier to continue to use an old and well-tried timber than to use a colonial substitute, however meritorious.

I know something of the practical difficulties which beset a timber merchant in Sydney, for instance, in obtaining a supply of a certain timber growing in a forest (say) hundreds of miles away, procuring it both true to name and in a seasoned condition. I have often pondered over the matter, and have wondered whether, seeing that the State is the principal proprietor of forests, and that it has already a staff of forest officers, whether State depôts (under lease or otherwise), might not be established, where stocks of timber might be held, such timber having been felled at the proper time, seasoned for a suitable period, and branded with a mark which would guarantee its true name. To carry out this plan rould necessarily require a State subsidy for a time, but I think that, under all the circumstances, a reasonable subsidy would be justifiably spent. In a few years I feel convinced that the advantages of seasonably felling, of seasoning, and of properly naming our timbers, would become so apparent that private enterprise would take matter up, and the State could withdraw from what might, at first sight, appear interference with private enterprise. We are at the present time giving our producers object lessons in many ways, and I do not think that a little State guidance in regard to the utilisation of our forest wealth would be either illogical or undesirable. It is, of course, understood that in making the abore crude suggestions, I am only expressing iny individual opinion. 


\section{Seasoning Processes.}

Some attention is being paid in the Colony, with fair success, to artificial processes for seasoning timber. Our native timbers are mostly dense and heavy, and are therefore peculiarly difficult to deal with. This matter of seasoning is important, as the natural drying process proceeds very slowly with hardwoods. A drawback to most artificial processes is that they impair the strength of the timber.

\section{Felling of Timber at proper Season.}

It is a matter for regret that, in the Australian colonies, timber-trees are felled the whole year round. It is generally accepted as a fact that timber from trees full of sap is more prone to warp and split, and even to decay, than timber from trees at rest, i.e., when the sap is down. No general rule can be laid down for all trees, all districts, and all seasons, but the simplest guide to the timber-getter is, when possible, to avoid cutting when the tree is seen to be bringing forth new leaves. It would not bo possible, under the present conditions of the timber trade, to carry out this rule in its entirety, but saw-millers would find it to their advantage to pay some attention to the matter, as it would improve the quality of their timber. If the State were to establish timber depôts, it might exercise strict control over the periods for felling timbers in the different districts. At the present time timbergetters and saw-millers will admit readily enough that timber should not be cut all the year round; but with the present cut-it-while-you-wait system which obtains, a reserve stock of logs is not felled (say) in the winter, to be hauled subsequently, but as a $\log$ is required it is felled there and then. With a proper system of scientific forestry we ought to have a close season for timber just as we have for game-birds.

\section{Common Names of Timbers.}

Our trade with other countries in timber will be mainly confined to our hardwoods, and therefore it is of paramount importance that a uniform system of nomenclature (at lenst for export purposes), should be agreed upon. I make the suggestion that our hardwoods should bear the official names given at pages 7 to 15 .

Howerer successful we may be in adopting an official vernacular nomenclature for export purposes, it is impossible to expect a uniform use of vernacular names in the Colony itself. People in one district look at the tint of the bark of a tree and call it "Blue gum"; in another district the wood is looked at, and, because it is red, the tree gets the name of "Redgum." These names are held with wonderful pertinacity, and, however desirable it may be, uniform names for many trees will never be agreed to. With our variable trees it may be that, as fresh differences are realised by the public, the number of names for what is really the same tree may increase rather than diminish. There are, however, some trees, such as bloodwood, that are known by the same name in all parts of the Colony.

\section{Botanical Names of Timbers.}

Botanical names will sometimes be omitted in referring to the timbers dealt with, to aroid repetition, but, in order that no doubt may arise as to the particular timber referred to, following is a list of the botanical names which have been so omitted. 
The botanical names are added in the text in some instances, simply for the sake of precision. The saw-miller or timber-merchant need not trouble his head about them.

Black pencil cedar, Panax elegans, Ch. Moore and F. v. M.

Brown or bully beech, Cryptocarya glaucescens (?), $\mathrm{R}$. $\mathrm{Br}$.

Brush Ironbark, Bridelia exaltata, T. v. M.

Cabbage paln, Livistona australis, Mart.

Cheesewood, Pittosporun of various species.

Corkwood, Duboisia myoporoides, R. Br.; Ackama IIuelleri, Benth, \&c.

Hickory or black wattle, Acacia binervata, DC.

Ironwood, Tarrietia argyrodendron, Benth.

Long jack, Flindersia.

Mangrove, Avicennia officinalis, $\mathrm{L}$.

Mountain ash, Eucalyptus virgata, Sieb. (Sieberiana, F. v. M.)

Native cherry, Exocarpus oupressiformis, Labill.

Native guava, Siphonodon australe, Benth.

Native orange, Capparis Mitchelli, Lindl.

Pigeon-berry ash, or native beech, Monotoca elliptica, R. Br.

Plumwood, Eucryphia Moorei, F. v. M.

Prickly tea-tree, Melaleuca styphelioides, Sm.

River oak, Casuarina glauca, Sieb, and Cunninghamiana, Mig.

Sassafras, Doryphora sassafras, Endl.

Scrub hickory, Pentaceras australis, Hk.

Soapwood, Evodia of various species.

Swamp oak, Casuarina glauca, Sieb., and Cunninghamiana, Miq.

Sweet-root, Alyxia buxifolia, R. Br.

Walking-stick palm, Kentia monostachya, F. v. M.

Water gum, Tristania laurina, R. Br.

White ash, Eucalyptus stricta, Sieb. var.

White holly, Pittosporum of various species.

White teak, Atalaya multiflora, Benth.

White tea-tree, Melaleuca lencadendra, L.

Wild lemon, Capparis nobilis, F. v. M.

The following list shows the various natural orders to which the timbers referred to in this pamphlet belong, and, consequently, in a measure, indicates their affinity.

\begin{tabular}{|c|c|}
\hline Tilincece & Echinocarpus. \\
\hline Meliacece & Dysoxylon. \\
\hline & $\begin{array}{l}\text { Owenia. } \\
\text { Cedrela. } \\
\text { Flindersia }\end{array}$ \\
\hline $\begin{array}{l}\text { Rhamnece } \\
\text { Sapindacece } \\
\text { Leguminosa }\end{array}$ & $\begin{array}{l}\text {.. Alphitonia. } \\
\text {... Harpullia. } \\
\text { e... Acacia. } \\
\text { Castanospermum. }\end{array}$ \\
\hline Myrtacea & $\begin{array}{l}\text {... Eucalyptus. } \\
\text { Tristania. } \\
\text { Syncarpia. }\end{array}$ \\
\hline
\end{tabular}

Compositce ... Olearia.

Verbenacece ... Gmelina.

Proteacece ... Banksia.

Grevillea.

Hakea.

Orites.

Stenocarpus.

Casuarinece... Casuarina.

Coniferce ... Callitris or Frenela. Araucaria.

Podocarpus.

Tristania. 


\section{CLASSIFICATION AND DESCRIPTION OF OUR COMMERCIAL TIMBERS.}

1. Ironbari of Various Kinds.

2. Pale Hardwoods:-

(a) Blackbutt.

(b) White mahogany.

(c) Tallow-wood.

(d) Spotted gum.

(e) Grey box.

3. Red HaRDwoods:-
(a) Red mahogany.
(b) Grey gum.
(c) Murray red gum.
(d) Forest red gum.
(e) Sydney blue gum.
(f) Woollybutt.
(g) Bloodwood.

4. Turpentine and Brugh-Box.

5. Crdar, Beech, and Pine, includina :-

(a) Red cedar.

(b) Rosewood.

(c) Red bean.

(d) Onionwood.

(e) Beech.

(f) Colonial pine.

(g) Brown or berry pine.

(h) Cypress pine.

6. SirkY $\mathrm{O}_{A \mathrm{~K}}$, SHE-OAK, \&c. :-
(a) Silky oak.
(b) Red silky oak or beefwood.
(c) Needlewood.
(d) Honeysuckle.
(e) She-oak.

7. Black Bean, Mrald, Blacriood, \&c.

8. Mrscelianeous Brusir Timbets: -

(a) Tulipwood.

(b) Muskwood.

(c) Flindosa or Cudgerie.

(d) Native teak.

(e) Blue-berry ash.

(f) Maiden's blush.

(g) Red ash.

(h) Corkwood, \&c. 
Just a word as to the aims and scope of this booklet. The difficulty has been not in regard to obtaining information, but in deciding what to leave out. If fuller information be desired in regard to a particular timber there will be no difficulty in procuring it.

In selecting the timbers for notice I have mainly confined myself to those most readily available to the denser populated eastern portion of the Colony, and to those most likely to be in demand for export. Many meritorious timbers I have not noticed, as, owing to the expense of land-carriage, their use is mainly confined to the districts in which they are found.

\section{IRONBARK.}

(An illustrated and descriptive article in regard to the various kinds of New South Wales ironbarks will be found in the Agricultural Gazette for October, 1893.)

Names.-We have four ironbarks, three of them of especial value. Timbers of this class are so important that it will be interesting to discriminate them. There is a good deal of confusion in regard to the local names given to ironbarks, and the names I suggest for the four species seem to me the least objectionable. At the same time the names "Narrow-leaved Ironbark" and "Broad-leaved Ironbark" are too cumbersome for ordinary use, and certainly for persons outside the Colony. It is probable that ironbark for the export trade will go forward under two names only, viz., grey ironbark and red ironbark, the first being the white or grey ironbark, and the second including both the "Narrow and Broad-leaved Ironbarks," the timbers of which elosely resemble each other. The fourth ironbark, whose botanical name is Eucalyptus sideroxylon, is mainly an interior species, and will seldom, if ever, be exported. Perhaps timber will go forward under the single generic name of ironbark ; if so, I wish to impress on friends at a distance that our various species of ironbark vary a good deal in colour, as a consignee may readily be confused if an ironbark be sent to him different in appearance to that to which he has been accustomed. Because of the great importance of ironbark, I proceed to deal with these timbers with a little more detail than with the other hardwoods.

Table of ironbarks.-The following table brings out the principal points in ironbark trees and iroubark timbers, and may help to elucidate them :-

\begin{tabular}{|c|c|c|c|c|}
\hline & $\begin{array}{l}\text { White or She Iron- } \\
\text { bark } \\
\text { (paniculata). }\end{array}$ & $\begin{array}{c}\text { Narrow-leaved Iron- } \\
\text { bark. } \\
\text { (crebra). }\end{array}$ & $\begin{array}{l}\text { Broad-leaved } \\
\text { Ironbark } \\
\text { (siderophloia). }\end{array}$ & $\begin{array}{l}\text { Red Iron- } \\
\text { bark - } \\
\text { (sideroxylon). }\end{array}$ \\
\hline $\begin{array}{l}\text { Colour (darkens } \\
\text { with age). }\end{array}$ & $\begin{array}{l}\text { Very pale; pink } \\
\text { when fresh. }\end{array}$ & Medium ... & $\begin{array}{l}\text { Mediun. } \\
\text { little darker } \\
\text { than preced. } \\
\text { ing. }\end{array}$ & Very dark. \\
\hline Strength of tim- & Best $\quad \ldots \quad \ldots$ & Good $\quad \ldots \quad \ldots$ & Good ... $\quad .$. & Inferior. \\
\hline Bark ... & $\begin{array}{l}\text { Oftenpale-coloured, } \\
\text { eren grey. Fur- } \\
\text { rows often anas- } \\
\text { tomosing. }\end{array}$ & $\begin{array}{l}\text { Very deeply fur- } \\
\text { rowed, inferior in } \\
\text { depth only (if } \\
\text { at all) to sider- } \\
\text { oxylon. }\end{array}$ & $\begin{array}{l}\text { Often of a flaky } \\
\text { character. }\end{array}$ & $\begin{array}{l}\text { Dark; } \\
\text { deepest fur- } \\
\text { rowed. }\end{array}$ \\
\hline Leaves ... & Narrow and medium & Very narrow & Very broad & $\begin{array}{l}\text { Medium; } \\
\text { foliage often } \\
\text { sparse. }\end{array}$ \\
\hline Flowers ... & White & White & White & Crimson ; \\
\hline Fruits $\ldots$ & Small & Very small & Rather large ... & Large. \\
\hline
\end{tabular}


How to tell ironbark.-It is not very easy, in a few words, to give a definition of ironbark. Of course, if the bark is available, the thing is simple enough, for most of the barks are characteristically furrowed and rugged. To describe it we must take note of a variety of circumstances. It is heavy (almost the heaviest of our hardwoods). It is hard, as may be readily seen if it be touched with a plane, or a nail be driven (or attempted to be driven), into it. Its most characteristic property, however, is a certain "gumminess" in working, which is well brought out under the plane, and its horny texture. The result is that, when planed, ironbark shows the appearance of nore or less parallel stria or lines of close-textured wood, strongly resembling horn, while between these, the wood has a more open grain, showing narrow pits which may be seen, even by the naked eye, to be filled by a substance of resinous texture. In some specimens it is not easy, however, to make out these lines of horny-textured wood, but the resin-pits appear to be always present. Ironbark is more or less curly in the grain, consequently it often gives. trouble to plane to a perfectly smooth surface. If a blunt tool be used, the ironbark tears in fairly regular blotches, while to get a perfectly smooth surface the wood often requires to be traversed with the plane, or even to be gone over with the steel scraper. Its hardness and weight often preclude it from use, perhaps an advantage, as otherwise the consumption of this timber would be inordinate.

Principal uses.-Ironbark is the king of New South Wrales hardwoods, in fact it is not excelled in any part of the continent for combined strength and durability. It is extensively used in bridge-construction, for railway sleepers, for posts, for naves, spokes, shafts, and framing, by the waggon and carriage-builder ; for large beams in buildings, particularly in stores for heavy goods-in a word, wherever great strength is required. For such purposes as railway-sleepers, it will last an indefinite period, and in many cases has to be taken up, not because it shows signs of decay from exposure on the permanent-way, or disintegration, because of the vibration to which it has been subjected, but because holes have been made in the sleeper by the renewal of bolts and spikes. I have specimens of sleepers which have borne the heaviest traffic of the main line near Sydney for twenty-five years, and which are as sound as the day they were laid.

\section{White or Grey Ironbark (Eucalyptus paniculata, Sm.)}

This is the ironbark usually called as above in the coast districts. It is, however, also called red ironbark in the Moruya and Wagonga districts, and other places.

The best white ironbark is very pale, the hardest of ironbarks, and cuts almost like horn; some of the same species from the Moruya district is of a medium red colour, not unlike Sydney blue gum in tint. It is to white ironbark of good quality that all the encomiums which have been passed on ironbark may be attributed. At the same time, timber but little inferior may be produced by some of the other ironbarks.

Distribution.-It is rather common in the coast districts and mountain ranges. Northward it extends as far as the Tweed, and southward to near Bega, perhaps further.

\section{Narrow-leaved Ironbark (Eucalyptus crebra, F. v. M.)}

So called because of its narrow, slender, graceful foliage, the flower-buds fiowers, and fruits being quite small. At Dubbo this timber is called both grey and red ironbark. 
This and the red (broad-leaved) ironbark may very well go together, as the timbers have much in common. They are of a deep red colour, of about equal hardness, and are really valuable timbers, although inferior to the best white or grey ironbark.

Distribution.-The narrow-leaved ironbark occurs principally on the eastern side of the Dividing Range, but at least as far south as Jervis Bay. It is common about Richmond, Wellington, also Dubbo to Narrabri. It is widely diffused, and a number of other localities could be given.

\section{The Broad-leaved Ironbark (Eucalyptus siderophloia, Benth.)}

Perhaps this is the most distinctive name for this species, a characteristic by which it may be readily distinguished, particularly in young trees, It is often called "red ironbark," particularly from northern localities. 'This ironbark from the Clarence and further north is apt to shell and split on exposure, and hence is not liked for engineering purposes. As a general rule it is a really fine ironbark. It resembles the previous one in quality of timber.

Distribution.-Broad-leaved ironbark occurs from the Clyde Mountains, in the south, along the coast ranges, to Queensland. Westward it is found as far as Wellington and Dubbo, also at Mudgee. Mr. Deane informs me that, with $E$. crebra, it is found from Dubbo to the north-western line.

\section{Red Ironbark (Eucalyptus sideroxylon, A. Cunn.)}

The wood of this is the deepest in colour, and also the softest and least valuable of the ironbarks. The tree is often pipy and gnarled, but in some places (e.g., the Mudgee district) it is a fine timber-tree. Where one of the other ironbarks is available, this ironbark suffers by comparison; nevertheless, it is a useful timber, and is employed in public works for such purposes as railway sleepers and posts, where long lengths are unnecessary. Frequently good lengths cannot be obtained, and if they could, the tensile strength of this timber is not equal to that of the best ironbark.

Sometimes it is called "Mugga," and it has been regarded with unreasoning prejudice, instead of being judged on its merits. To call any timber by such a name as "Mugga" is to inflict an irreparable injury upon it.

Distribution.-Red ironbark is found principally in the auriferous districts of the western and south-western interior. It is generally found on poor, sterile ranges, and is usually unaccompanied by any other species of ironbark.

I have dealt with the question of distribution in speaking of individual ironbarks. But as regards the coast ironbarks, the most important commercially, it may be pointed out that they and spotted gum often grow together. The principal localities on the south coast are Bermagui, Red Head, Wagonga, Moruya, and the Clyde River. On the north coast we hare Wyong, Ourimbah, Blue Gum Flat, Port Stephens, Cape Hawke, Manning River, Oamden Haven, Port Macquarie, and so on to the Tweed.

Quantity available.-In spite of the reckless extravagance with which this timber has been cut, it is by no means scarce, especially in some localities, a few miles from the coast. While it is a very slow-growing tree, there is some consolation in the fact that it usually grows in barren, rocky country, unsuitable for agriculture, and therefore wholesale clearings are not made as is the case with many other timbers. At the same time it does not readily reafforest. 


\section{PALE HARDWOODS.}

This is a convenient practical classification. Some of the most raluable hardwoods of the Colony belong to this class, and injury has been done to some of them because unscrupulous persons in this and other colonies have endeavoured to persuade buyers that certain pale hardwoods, which are never used in the colonies except for temporary and inferior purposes, are genuine blackbutt, \&c., or equal in quality to such timbers.

\section{(a) Blackbutt (Eucalyptus pilularis, Sm.)}

(An illustrated article descriptive of this timber will be found in the Agricultural Gacette for October, 1894.)

Name.-O king to the fibrous bark on the butt, which is of a dark-grey colour, even blackish, though its depth of tint is in part often owing to bush fires.

Characteristics.-Pale-coloured, more or less fissile, though sometimes quite interlocked in grain. It is a strong, durable, thoroughly safe and well-tried timber. It is usually readily diagnosed by the presence of narrow, concentric gum-veins, but sometimes these veins are nearly or wholly absent.

Principal uses.-This is one of the best hardwoods we have for house and ship-building. It is useful for bridge planking, though inferior to tallowwood for that purpose. It has been tested for many years for blocks for wood-paring, with most satisfactory results; in fact, it is one of the best timbers we have for the purpose, both as regards wear and durability. It takes tar well. After ironbark, I would only place this timber second to tallow-wood, amongst our hardwoods, for general purposes.

Distribution.-Coast districts from north to south.

Quantity available.-Plentiful.

\section{(b) White Mahogany (Ericalyptus acmenoides, Schauer.)}

Name.-This is a pale-coloured timber, which bears no resemblance either to the mahogany of commerce or to the red or forest mahogany of New South Wales. It gets its name because of its pale colour, and because the bark of the tree was thought to resemble that of the red mahogany. The name is in universal use in the Colony, and cannot now be disturbed.

Characteristics.-To say that it resembles tallow-wood a good deal, but that it is paler in colour, that it is not greasy, and harder than the better known timber, will perhaps give a good idea of it. It is one of the most durable timbers in New South Wales. I know of posts of it in different parts of the Colony quite sound after the vicissitudes of more than half a century. Its chief drawback is some tendency to shell off. Users of it assure me that it is far more durable than ironbark or box. It is a tough, strong useful timber.

Principal uses.-I believe it will be found an excellent timber for woodblocks, but I would discourage exportation of it at present except under close supervision, as I have lnown stringybark substituted for it, perhaps through inadvertence. Its hardness is a drawback, and the trees are sometimes unsound; but it is so good a timber that I would invite our timber men to give more attention to it in future. It is one of those timbers which is not as well known as it should be, because it has been constantly confused with 
others. It is excellent for posts, piles, girders, se, and is useful for general building purposes. It would be desirable to thoronghly test it for the decking of bridges.

Distribation.- North coast and coast monntain districts.

Guantity available.- Tot one of our most plentiful timbers, but still fairly abundant.

\section{(c) Tallow-wood (Eucalyptus micricorys, F. v. M.)}

(An illustrated descriptive article on this timber will be fomd in the Agricultural Gazette for May, 1894.)

\section{Name.-Giren because of its slippery, greasy nature.}

Characteristics. - Of a canary-yellow (or sometimes reddish) colour when freshly sawn, drying to a pale brown. One of the least liable to shrink of all our hardwoods. It is hearr, strong, and durable. It may be planed and turned with great satisfaction. It is not easily split, the greasy substance contained in it making it a tedious matter to get the wedge to "draw." I would express the opinion that, after ironbark, tallow-wood is the most valuable of our hardwoods.

Principal uses. - For flooring, particularly in ball-rooms. For this latter parpose it is selected on account of its greasy nature. For decking, handrailing, girders, and some other parts of bridges. I farourite for buildingwork generally. It does not burn readily, which in buildings is, of course, a recommendation. It is perhaps the most valnable wood in New South Wales for paving-blocks. It makes admirable posts and rails. lasting an indefinite period either above or below ground, but difficult to split for these purposes, as already remarked. White mahogany is not infrequently substituted for tallow-rood. Both are good timbers, and can stand on their own merits. The substitution can be readily detected by any man with a fair knowledge of colonial timbers.

Distribution.-Coast district and Dividing Range, from Newcastle northward.

Quantity acailable.-Fairly abundant.

(d) Spotted Gum (Eucalyptus maculats, Hook. f., ).

Name.-This is a smooth-barked tree, but which has blotches of a whitish colour on the bark, owing to the outer layer of bark peeling off in patches. This gives the tronk a spotted appearance.

Characteristics. - I pale yellowish brown timber, usually with a pretty, wary grain, which looks well nnder polish. It is particnlarly tough, and it is one of the best of our timbers for bending, even when cold. It is rers durable, though its sapwood is particularty liable to decay.

Principal uses.-For wheelwrights' and coach-builders' work, it is for some uses unequalled amongst colonial timbers. Its porer of bending into various shapes is rery useful. It is used for cross-pieces, shafte, and poles for drays, baggies, naves, and spokes, handles, agricultural implements, boring-rods (artesian), framing and house-building generally, tram-rails for the converance of logs from the forest to the mill, bridge-decking and shipplanking. In rier of the conflicting statements which have been made in regand to the durability of this timber for wood-paring, the Minister for Mines and Agriculture appointed a committee of experts to inquire into the 
matter. Their report will be found in an early issue of the Agricultural Gazette, and will be found to contain a considerable amount of information in regard to the merits of this timber for purposes other than wood-paving.

Distribution.-North and south coast districts, but particularly in the south.

Quantity available.-Fairly abundant.

\section{(e) Grey Box (Eucalyptus hemiphloin, F. v. M.)}

Name.-Because of its tough, inlocked character, which reminded the early settlers of Turkey box. Here, however, the resemblance ceases, as our box is a coarser-grained, duller-looking timber, while in the colonies it often goes by the name of "Box," the adjective "Grey" being used to distinguish it from red box, brush-box, \&c.

Characteristics.-Its toughness, hardness, cross-grained, non-fissile character, and its great strength. It is a pale hardwood, of a very pale brown.

Principal uses.-It is used in the colonies for the naves of wheels and heavy framing, and for the cogs of wheels, large screws, mauls, handles, shafts, poles of drays, \&c., which require a tough wood for their manufacture. In Victoria it is in high repute for railway sleepers, and in that colony and our own for piles, girders, \&c. It can be recommended with confidence to railway-carriage builders and others who require a strong, durable timber for framing, \&c.

Distribution.-Coast and coast mountain districts.

Quantity available.-Fairly abundant.

\section{RED HARDWOODS.}

(a) Red Mahogany (Eucalyptus resinifera, $\mathrm{Sm}$.)

(See an illustrated and descriptive article on the various so-called mahoganies of $\mathrm{New}$ South Wales in the Agricultural Gazette for January, 1895.)

Name.-This is the timber called mahogany, because it reminded the early settlers of the Central American wood, which is, however, of much less weight than our timber. Our timber-getters and saw-millers as often. as not call it simply " mahogany," but, in view of the better known mahogany so largely used in the northern hemisphere, it would only lead to confusion, if our timber were exported without some qualifying adjective. I would, therefore, express the hope that it be consistently called, by way of distinction (at all events in the export trade) "red mahogany," a term which is, of course, very largely applied in the Colony to this timber.

\section{Other local names. - "Forest mahogany" is a term often used.}

Characteristics. - Of a rich red colour. Tery durable, and becoming very hard with age, even as hard, or harder than ironbark. Resistant to white ants, and does not discolour paint.

Principal uses.-For general building purposes and for fencing, as it is a very durable timber. It is an excellent timber for wood-paving, but while not depreciating its value in this direction for a moment, I would point out that there is just a little danger of our forgetting the merits of other valuable paving timbers. Red mahogany is often sold as jarrah, which it closely resembles, and for which I believe it is a perfect substitute. But there are fashions and fads in paving-blocks, as in many other things, and European users of our hardwoods should be reminded that we have a number of other 
meritorious timbers to offer them. It is of a handsome colour, and works up well. It may be recommended for large turned work, and for heavy furniture. It is useful for weather-boards.

Distribution.-North coast districts.

Quantity available.-Fairly plentiful, though not so readily accessible as formerly, owing to the great demand for it.

\section{(b) Grey Gum (Eucalyptus propinqua, Deane et Maiden.)}

Name.-Because of the dull grey appearance of the bark. The bark has a roughish appearance, in contradistinction to a smooth and even shiny one, possessed by so many of our gums. It has smooth white patehes in places, caused by the outer layer of bark falling off. These white patches in their turn become grey, and the process of exfoliation of the bark is repeated until probably the whole of the bark on the trunk is shed at one time or another. Although rather difficult to properly describe, the bark of the grey gum is so characteristic, that when once pointed out, it could not be confused with the bark of any other hardwood tree.

Characteristics.-It is so much like ironbark in appearance that it is difficult to discriminate between the two timbers. That will be the best guide to its appearance. An expert would usually detect the substitution for ironbark (if he suspected any substitution), by noting that a chip of grey gum is more brittle than that of ironbark. It also cuts less horny. Nevertheless, the two timbers are wonderfully alike, and for many purposes grey gum is an efficient substitute for ironbark, for it is remarkably durable. Its inferior strength, as compared with ironbark, precludes its use as girders of any length, and when substituted for irontark in sleepers, the bolts and spikes work loose in them. I would encourage its use in every possible way for wood-blocks. The chief objectors to its use at the present time are the sawmillers themselves, as the logs often contain gum-scabs or gum-veins. At present, where unblemished timber is insisted upon for wood-blocks, a sawmiller cannot afford to cut up grey gum (although it frequently turns out unblemished), because of the risk of having it condemned. I have spoken on this subject in connection with bloodwood (see page 16), and would emphasise the opinion that wood-blocks should not be condemned because they contain a few gum-acabs or veins. Such excess of care practically leads to great waste of really valuable timber.

Principal uses.-Recommended for paring-blocks, as already stated. It is in high repute for posts, having excellent records when employed in this very trying situation. I have seen it used for felloes and for shingles. It is very largely used as an ironbark substitute for railway sleepers, \&c., which fact is in itself testimony to its excellence.

Distribution.-Northern coast districts.

Quantity available.-Plentiful.

(c) Murray Red gum (Eucalyptus rostrata, Schlecht.)

(An illnstrated article descriptive of this timber will be found in the Agricultural Gazetie for February, 1893.)

Name.-This is the red gum par excellence of the Colonies of New South Wales, Victoria, and South Australia. The term "gum" is applied in Australia to those species of Eucalyptus which have smooth barks. This is called "red gum", because it has a red timber. I propose the name "Murray red gum" for it, as it is abundant on the river of that name, and to aroid confusion with the closely-related "forest red gum." 
Characteristics.-Its red colour, its strength and durability, resistance to fungus diseases, wlite ants, teredo, \&c. In common with many of its congeners, it is very hard to work up when dry, A drawback to this admittedly valuable timber is some tendency to shell off, which limits its use for such purposes as flooring and decking.

Principal uses.-Its durability causes it to be largely used in the colonies for posts and piles in damp ground. It is largely employed in Victoria for railway sleepers, for which purpose it is undoubtedly yaluable, though inferior to irombark. It is an excellent girder-wood. It is a good timber for wood-paving, though inferior to some others by reason of its tendency to warp and shrink during the process of seasoning.

Distribution.--River banks of the interior, but particularly abundant and readily available in the valleys of the rivers Murray (which forms the greater part of the boundary between New South Wales and Victoria) and Edwards, one of its tributaries. As regards the Murray, nearly the whole of the red gum is on the New South Wales side.

Quantity available.-Practically unlimited, as the forests where the red gum grows are liable to inundation, and therefore not available for settlement. For geographical reasons no red gum is shipped at a New South Wales port, moat of this timber going to Victoria.

\section{(d) Forest Red Gum (Eucalyptus tereticornis, Sm.)}

Name.-This tree is very closely related to the Murray red gum, which is always found near watercourses, or on alluvial country. The tree at present under notice is always found in open forest country; hence I recommend the adoptiou of the prefix "forest" to red gum, the name by which it is very commonly known, with the view to save confusion.

Other local names.-Blue and grey gum, and even others, but these names are best reserved for other trees.

Characteristics.-Of a deep red colour, hard and inlocked in the grain, heavy and durable. Apt to warp in seasoning, and with properties much the same as Murray red gum.

Principal uses.-Much esteemed for fence-posts, its great durability for this purpose having been long established. Used also for naves and felloes of wheels, and for general building purposes. Its merits and defects are much the same as those of Murray red gum, and I draw attention to it as a meritorious timber for wood-blocks.

Distribution.-Widely distributed in the Colony throughout its entire length, in the coast and coast mountain districts, and table-lands. It attains its best development south of Sydney.

Quantity available.-Abundant.

\section{(e) Sydney Blue Gum (Eucalyptus saligna, Sm.)}

(An illustrated article on this timber will be found in the Agricultural Gazette for November, 1894.)

Name.-This timber requires some distinctive designation to prevent its confusion with the pale-coloured blue gum of Tasmania and Victoria. I hare elsewhere called it New South Wales blue gum, by way of distinction, but as this is such a ponderous name, that of "Sydney blue gum" may be more acceptable.

Other local names.-In the south const district sometimes it is called "woollybutt," because of its confusion with the true woollybutt, the two 
trees resembling each other a good deal in this particular district. I draw attention to the matter in this connection, because, in this district at least, our blue gum is inferior in durability to the true woollybutt, so much so that it is there rarely used for posts and other underground work.

Characteristics.-Of a pale red colour, straight in the grain, comparatively easy to work, and, therefore, for a hardwood, a favourite with carpenters.

Principal uses.-It is largely used by shipwrights and wheelwrights, and is a very useful hardwood. It is extensively used for building purposes, ships' planks, \&c., and is the most widely used of our timbers for felloes of wheels. Although this timber varies a good deal in quality, much of it, and particularly that found in the northern parts of the Colony, is very durable, and has been used with wood-blocks with much success. I confidently recommend sound, mature, Sydney blue gum for this important purpose.

Distribution.-Coast and coast ranges, north and south. .

Quantity available.-Plentiful.

(f) Woollybutt (Eucalyptus longifolia, Link et Otto.)

Name.-The bark is of a dirty grey, brittle, fibrous character, and was thought to be of a woolly texture. It often resembles box bark a good deal.

Other local names.-This tree often goes by the names of peppermint and redwood in the south coast district, the latter name being used for obvious reasons, and the former because the bark resembles that of another Eucalyptus tree, known as peppermint, both in texture and in being persistent to the ultimate branchlets.

Characteristics.-Dark red, of a wavy grain, rather heavy, and not unlike red ironbark in general appearance, for which more valuable timber it is sometimes substituted. It is a very durable timber, but deficient in strength and elasticity, particularly near the heart. Many of the trees also are faulty, and hence it is not a favourite with saw-millers.

Principal uses.-For posts, for which it is a favourite in the south coast district, because of its durability. I draw attention to it at the present time because I look upon it as a really valuable timber for wood-paving. It is not our best timber for the purpose, but is of proved value under very trying circumstances as regards exposure. Like red mahogany and others of our timbers it belongs to the jarrah class. Although it has been passed off as ironbark sleepers and even girders, it is an inferior timber on account of its comparative brittleness, a defect which would not in any way affect its usefulness for wood-blocking.

Distribution.-Coast districts, from Sydney southward.

Quantity available.-Plentiful.

\section{(g) Bloodwood (Eucalyptus corymbosa, Sm.)}

Name.- So called because of the large quantity of a blood-like fluid (gum, or kino) which exudes from the tree, and which, when indurated, forms the gum-veins so common in this timber.

Characteristics. - Liability to shell concentrically, the spaces thus formed being often filled with the red astringent substance known as "gum." One of the most durable of all Australian timbers. It does not split at the ends when exposed to the sun, as many of our timbers do. 
Principal uses.-For such purposes as a durable timber is required. For posts in the ground, and for use in culverts, it is all but imperishable. The great drawback to this timber is its liability to gum-veins, but in spite of this, I include it in the present list, as I look upon much of the prejudice against bloodwood as unreasonable. It would be unacceptable for export, as we have abundance of better timbers, but I certainly think it ought to be used more than it is where readily arailable. I would encourage its use by public officers for fencing, culverts, wharves, \&c. Where not too defective, I should look upon it as an ideal timber for wood-paving. By too defective I refer to cases where the timber shells too much; but the presence of gum-veins of moderate wilth in timbers such as this, and grey gum, I would not look upon as an important defect in wood-blocks, as this astringent "gum" tends to preserve the block rather than injure it. I have seen timber rejected for wood-blocks because of gum-scabs and gum-veins, which would, of course, be inadmissible in a furniture wood, for instance, but which would in no way be detrimental to a wood-pavement. The scrupulous care which is insisted upon in some contracts to reject wood-blocks because of gum-veins, sometimes degenerates into mere faddism, and it is only possible to select so severely, because at present we have an enormous timber supply to fall back upon. I would, therefore, recommend the framing of woodblock contracts in such a way as to allow the inspecting officer some latitude in dealing with timber containing gum-veins. Occasionally, bloodwood is found pretty free from gum-reins, or the veins are wide apart. When this is the case it is sometimes cut up for lining-boar ds in country districts.

Distritution.-Coast districts and Blue Mountains.

Quantity available.-Fairly plentiful.

\section{TURPENTINE AND BRUSH-BOX.}

\section{Turpentine (Syncarpia laurifolia, Ten.)}

(An illustrated article descriptive of this timber will be found in the Agricultural Gazetle for July, 1894. A subsequent report has also been furnished to the Minister in regard to the immunity of this timber from cobra (Teredo) when used for piling, and will shortly be published in the Agricultural Gazetle.

Name.-From the resinous exudation which flows from between the bark and the wood when the timber is cut into. It is an unfortunate name, as it suggests inflammability, and turpentine is one of the most uninflammable of timbers. In some districts the fresh red-coloured turpentine is called " red turpentine" to distinguish it from the chocolate or dark-brown coloured timber known as "black turpentine." They are the same timber, the latter being either over-matured, or suffering from incipient decay.

Characteristics. - In colour it is usually dull red, but it varies to brown or purple-brown, as already mentioned. It has very little tigure. It requires careful seasoning. It dulls the saws. Its chief recommendation is its durability, resisting decay in the ground, whether from white ant or other causes, while it is one of the best timbers we have for resisting marine borers, especially if the bark be intact. It is very difficult to burn, a great recommendation to its use in buildings. It will thus be seen that the properties of turpentine, those at least which give it its value, are mostly of a negative character.

Principal uses.-Chiefly for piles for bridges, wharfs, and jetties. They should be driven with the bark intact, as much of its power of resistance to cobra, \&c., is apparently due to the presence of a layer of oleo-resin between 
the timber and the bark. Turpentine piles resist marine borers in sea-water better than those of any other abundant timber. In brackish water they are destroyed by cobra, \&c., like most of our other timbers. In fact no unprotected timber is afe in our brackish northern rivers. Turpentine is used also for fencing-posts, also for pillars and girders in buildings. It is also a useful second-class timber for wood-paring.

Distribution.- Throughout the coast and coast mountain districts from the Shoalhaven to the Tweed. It attains its greatest luxuriance in deep, sheliered gullies with good soil.

Quantity available.-Very abundant, as its chief utilisation at present is for piles and hewn-posts and rails, since saw-millers dislike it exceedingly, as it rapidly dulls their saws.

\section{Brush-box (Tristania conferta, R. Br.)}

Name.-_ "Box" owing to the timber being tough and inlocked; "brush" because it is essentially a brush (a colonial word for luxuriant vegetation, jungle in fact) timber. The name "brush-box" distinguishes it also from "forest or grey box" (Eucalyptus hemiphloia).

Other local names.-"Woollybutt" in use in the Port Stephens district as well as on the Manning.

Characteristics.-Its toughness, strength, and durable qualities. It has a more than usual tendency to warp and twist, which could be largely counteracted by felling at the proper season, and by giving some attention to seasoning. It is one of the timbers most obnoxious to white ants. It is pale-coloured, usually brownish to pinkish, and turing greyish on exposure. Dulls the saws.

Principal uses.-The timber perhaps universally used in the northern districts for tram-rails for haulage of the logs from the forest to the sawmill. It is not cut by the iron wheels, but bacomes polished by the traction, while it is eminently durable. Much used for bullock-yokes. I am of opinion that if proper attention were paid to the time of felling, and if it were moderately seasoned, it would be a useful timber for paving-blocks. I also am of opinion that the question of its suitability for bridge-decking should form the subject of careful inquiry. I have sezn inch boards of this timber exposed to the atmosphere for months without warping; at the same time that it warps a good deal if cut all through the year, and never seasoned, is notorious. Owing to its toughness it is used locally for mallets, chiselhandles, planes, jaws of hand-screws, \&c.

Distribution.-Port Stephens to the Tweed, within the coast range. Usually in brushes, but often in open forests.

Quantity available.-Very large quantities.

\section{CEDAR, BEECH, AND PINE.}

(a) Red Cedar, Cedar, \&c. (Cedrela australis, F. v. M.)

(An exhaustive account of this timber, with a botanical illustration, will be found in the Agricultural Gazotte for August, 1893.)

Name.-Because it is supposed to resemble the pencil cedar (Juniperus) of commerce; "red" cedar, to distinguish it from the white, yellow, and brown cedar of this Colony.

Characteristics.-Resembles the mahogany of commerce a good deal, with the advantage of possessing only half its weight. Red, darkens with age, of 
good appearance, while figured pieces are of great beauty. Easily worked, soft, yet very durable. It would be difficult to exaggerate the good qualities of this valuable timber.

Principal uses.-The principal timber used in the Colony for the better kinds of furniture and house-joinery. It would be impossible to enumerate the uses to which it is put-fresh ones being continually found. A recent use is for railway keys (between chair and rail).

Distribution.-From the Shoalhaven to Queensland, but in greatest abundance and best quality from the Richmond River to the Tweed.

Quantity available.-Only moderately plentiful, having been such a favourite timber for nearly a century.

\section{(b) Rosewood (Dysoxylon Fraserianum, Benth.)}

Nane.-Because of the odour of the freshly cut timber.

Characteristics. - Of a reddish colour, and has a neat figure. Has a fragrant rose-odour when fresh, though the perfume is fugitive. A timber of the mahogany class. Works splendidly.

Principal uses.-Furniture, cabinet-work, turnery, carving, and indoor work of all kinds. It is used for newels, mouldings, and framing of all sorts. Useful for show-case work, also for planes, levers, trundles, and studs in roller-boards of organs, \&c., window-jambs, screws of hand-screws, and any uses where a wood a little harder than softwood is required. Recent test uses are for bee-boxes, broom-handles, and wire-mattress frames. Has been strongly recommended for wine casks. It will split, and I am assured it imparts no taste to wine. Very durable and resistant to white ant, e.g., often used for house-blocks in the Kempsey district.

Distribution.-Brush forests, northern districts, from Wyong northwards.

Quantity available.-Practically unlimited. I look upon this as a valuable reserve timber. Its usefulness will be realised later on, when cedar is even searcer than it is.

(c) Red Bean (Dysoxylon Mruelleri, Benth,)

Name.-To distinguish it from "black bean" (Castanospermum), but this is quite unnecessary, as the two timbers are as different from each other as they can well be.

Characteristics. - Red bean may be described as a scentless rosewood, of a red colour, and possessing a neat figure.

Principal uses.-This timber is often sold in Sydney as cedar or bastard cedar, but it is of sufficient excellence to stand on its own merits. It is a good furniture wood, and has a quiet yet handsome figure that looks well under polish. It can be put to most of the uses that Spanish mahogany is put. I have heard that it is considered valuable for the naves of wheels in the districts in which it grows.

Distribution.-Northern rivers, particularly the Clarence and Richmond. Quantity available.-Not large.

(d) Onionwood (Owenia cepiodora, F. v. M.)

This is a useful wood of the cedar class - the wood, in fact, being often sold as bastard cedar. The name is owing to the smell of the wood, which is fugitive and therefore not offensive. Used for the same purposes as cedar. Plentiful in the Richmond River district, and scattered in nearly all the brush forests of the Tweed. 
(e) White Beech (Gmelina Lieichhardtii, F. v. M.)

(An illustrated article descriptive of this timber will be found in the Agricultural Gazetle for May, 1895.)

Name.-This timber is consistently styled beech or white beech, and is the principal timber called beech in the Colony, although other timbers pass under the name of she-beech, brown beech, \&c. Our timber is paler in colour, softer, and is quite a different timber to the beech of Europe.

Characteristics.-Pale-coloured,-white with a tinge of brown. As a very general rule it is plain, but occasionally it shows a neat grain, which is ornamental. It is rather close-grained and excellent to work. It does not expand in damp or contract in dry weather if moderately seasoned; in fact, it is one of our few commercial timbers that can be put to use almost as soon as it can be converted into sawn-stuff, although, of course, it is better for seasoning.

Principal uses.-It is used for very many purposes where a timber harder and more durable than pine, and softer than hardwood is required. Its chief use is for flooring-boards, chiefly of verandahs, and for decks of vessels, because it shrinks so little. It would be almost impossible to misplace for ordinary carpentry purposes, and it is commonly used for house-fittings, floats of mill-wheels, ships' blocks, picture frames, \&c. It is an excellent wood for carving, and a well-known vigneron pronounces it to be better than oak for the larger casks, aud vats for colonial wine.

Distribution.-In the coast and coast mountain districts from the Shoalhaven northward, but chiefly north of Port Stephens.

Quantity available.-Not abundant.

(f) Colonial or Moreton Bay Pine (Araucaria Cunninghamii, Ait.)

(An illustrated article on this timber-tree will be found in the Agricullural Gazette for June, 1895.)

Name.-Called "Moreton Bay pine," because at one time it was largely supplied to Sydney from the Moreton Bay (Brisbane) district.

Other names.-."White pine," "Richmond River pine" (because it is so plentiful in that district of northern New South Wales), and "Hoop pine.", The origin of the last name is thus explained. The bark is of a tough nature, and does not readily decay on exposure. The timber itself is peculiarly liable to decay under such circumstances, and so it happens that when a tree is felled in the forest and chopped into lengths, if allowed to remain, all the wood disappears, leaving the bark as a "hoop" or natural pipe, reminding one of a pipe for water supply.

Characteristics.-A softwood, not of high class. Durable when used for such purposes as house-fittings, and kept dry, but very liable to decay on exposure. It is apt to get of a dirty colour with age. Planks often show a peculiar dotted appearance, comparable to a bird's-eye maple figure, though less handsome.

Principal uses.-This is our principal cheap softwood, and will only be available for local use, as the piue timbers of Europe and America are of far superior quality. It is largely used for flooring, lining and ceiling boards, for packing-cases, and for many other purposes where an easily-worked, cheap softwood is required. There is one use, and an increasingly important one, to which colonial pine may be put, and I ask our Richnond and Clarence Rirer millers to take it to beart. I allude to butter-boxes. An enormous quantity is required every year for New South Wales butter, and 
yet this Colony, with all its pine forests, fails to supply timber to case its own butter. I believe the wood to be a suitable one for the purpose, but some of our northern saw-millers hardly realise that they are allowing a good trade to slip away. Colonial pine is very light when well seasoned, and it may be cheaply coated with a thin layer of paraffin, if necessary.

Distribution.-From the Bellinger River to Northern Queensland, the timber obtained from the high lands near the sources of the northern rivers being far superior in quality to that growing on the low lauds near the coast.

Quantity available.-Fairly abundant.

(g) Brown Pine (Podocarpus elata, R. Br.)

We hare another timber allied to "colonial pine," but much harder and more durable, namely, that one which is variously known as "brown pine," "she-pine," "plum pine," and "berry pine." The timber is used for miscellaneous purposes, like "colonial pine," but its most valuable property is its resistance to white ants and Teredo. Round piles of this timber, with the bark on, are all but proof against the attacks of Teredo (cobra), even in brackish water. In fact, some saw-millers say that its power of resistance to marine borers is absolute, but $I$ doubt this, although it is very rarely touched.

\section{(h) Cypress Pine (Callitris, of which Frenela is a synonym).}

Name.-Under the general name of cypress pine we include a number of Australian trees which, though not true cypresses, more or less resemble those trees in general appearance. They belong to the genus Callitris, and are very closely related to the North African tree ( $C$. quadrivalvis), which prodices the sandarach of commeree. Our principal species are known as led or black pine (Callitris calcarata, R. Br.), Murray or white pine ( $C$. verrucosa, R. Br.), Richmond River cypress pine (C. columellaris, F. v. M.), and Port Macquarie pine (O. Macleayana, F. v. M.)

Characteristics.-Its pleasant odour,-camphoraceous, or sometimes reminding one of andal-wood. Its great power of resistance to insect pests. It is said to be absolutely resistant to white ant, but that is overstating the case. Nevertheless cypress pine is about the very last timber that white ants will attack. Some of the species, the red or black pine in particular, produce very showy timber; in fact many of the planks are so gorgeous in appearance that care is required in using it for decorative purposes, lest it should have too overpowering an effect. At the same time much of the timber is of a quiet handsome character. The prevailing colour of the figure is brown of various shades. Drawbacks to cypress pine timber are its brittleness; it will therefore stand but little transverse strain, and a nail can hardly be driven into the wood without previous boring, for fear of splitting the timber. Another drawback is its great inflammability. It may be readily dressed up to a smooth and glossy surface.

Principal uses.-It is extensively used in buildings liable to attack by white ants, and I think if its value were better known in the coast districts it would be employed to a greater extent. It is used to an enormous extent a couple of hundred miles and more back from the coast for house-blocks, linings, and ceilings of houses. Land carriage would effectually stand in the way of our profitably shipping this timber, eren if an outside demand were to spring up for it, of which wo have no evidence at present. It is one of the most luxurious firewoods I know of; it burns well, and in burning 
emits a delicious tragrance very geverally admired. My idea is that the small pieces produced in saw-mills would sell at a remunerative price as a superior kind of fuel for drawing-rooms, \&c., if people could only readily obtain it. This may appear to be a trifling matter, but I think that minor uses of our timbers (and above all, utilisation of waste), should be looked to. In developing such enterprises of magnitude as the wood-block trade, or the getting out of railway sleepers and timbers for bridge-work, we should not lose sight of the smaller possibilities of some of our timbers.

Distribution.-Chiefly in the drier parts of the Colony, but some is avaìable in the north coast district.

Quantity available.-Large.

\section{SILKY OAK, SHE-OAK, \&c.}

(a) Silky Oak (Grevillea robusta, A. Cunn., and Orites excelsa, R. Br.)

(An illustrated article descriptive of this timber will be found in the Agricultural Gazette for September, 1893).

Name.-When split on the quarter this timber shows a handsome oak-like grain, the prefix "silky" being either because of the silky underside of the leaves, or on account of the bright appearance of the freshly split wood. The name " silky oak" has for many years been thought to exclusively apply to Grevillea robusta, but I have shown that the strikingly similar timber of the botanically closely-related Orites excelsa also goes under the naine of silky oak.

Characteristics.-Its fissility. It is light in colour, and its handsome figure has already been alluded to.

Principal uses.-For casks of various kinds, principally wine and tallow. It has also been largely used for butter kegs. For all these purposes it must be cut or sawn on the quarter, to avoid leakage or soakage. In the old days before the advent of galvanised iron, it was almost exclusirely used in the northern districts for milk-buckets and dairy utensils, for which purposes it gave great satisfaction. The extension of the use of butter-boxes is causing butter-kegs to be superseded, and therefore increased attention should be given to the utilisation of this timber for dairy appliances of various kinds, e.g., hands, pats, and rammers for butter. If our timber merchants would study the special requirements of butter factories and firms and companies who deal wholesale in or who export this important commodity, they would find that it would be to their advantage.

Distribution.-Grevillea robusta, in the brush forests from the Clarence northwards; Orites excelsa, on the table-lands from Mount Royal in the Singleton district, northward, in brush forests.

Quantity available.-Grevillea robusta has been so appreciated that it is not now very abundant, but Orites excelsa is at present abundant, and will relieve the demand for the other timber. They are practically identical.

\section{(b) Red Silky Oak or Beefwood (Stenocarpus salignus, R. Br.)}

A reddish, fissile timber, used locally for furniture, veneers, staves, gunstocks, walking-sticks, picture frames, \&c. This timber is an efficient substitute for the northern silky oaks (Grevillea and Orites); in fact it has been long used by the Illawarra dairy farmers for such purposes as butter kegs. 
Other timbers of minor importance belonging to the Honeysuckle family are :-

\section{(c) Needlewood (Hakea leucoptera, R. Br.)}

Whose wood, or rather the root-stock, has been used for making pipes for very many years by bushmen. I have heard experienced smokers say that it produces the coolest pipes they have ever used.

\section{(d) Honeysuckle (Banksia).}

We have two principal speeies, but although the wood of both is esteemed locally for various purposes, neither is likely to be in demand outside the colonies. White honeysuckle (Banksia integrifolia, Linn.) is a pinkish timber showing a neat grain. It is, however, but little used on account of its ornamental character, being chiefly employed for ribs and knees in boatbuilding, bullock yokes, \&c. Minor uses are wood screws, bow-saw frames, walking sticks, and clean turnery generally. Red honeysuckle ( $B$. serrata, Linn. f.) is a coarser, redder timber. It is largely used for boat-knees.

\section{(e) She-oaks (Casuarina of various apecies).}

Name.-All over Australia, in most of the coast districts as well as in the arid interior, we have a class of trees bearing no leaves, and reminding the early colonists of the fir-trees of Europe. The trees have, usually, drooping wiry branches, commonly known as "leaves," because they remind one of fir or pine leares, and are known as "oaks" or "she-oaks," because of the oaklike grain of the timber. Various species of she-oak go under the name of "forest oak," "river oak," "swamp oak," "bull oak," "belar," " beefwood," "black oak." These are the principal names, but there are a number of others. In the English market the darker kinds are known under the name of "Botany oak."

Oharacteristics.-Our she-oaks vary so much in depth of tint, in the extent and distribution of the blotchy grain to which the wood owes so much of its beauty, that it is difficult to describe it by any brief general description. Some of the deep-red kinds imported into England at one time very largely, Mr. Holtzapffel, the well-known authority on turnery, describes as "in general colour resembling a full red mahogany, with darker red veins; the grain is more like the evergreen oak (Quercus Ilex, a Mediterranean species), than the other European varieties, as the veins are small, slightly curled, and closely distributed throughout the whole surface. Some specimens are very pretty." Most of our she-oaks are very fissile, and show a handsome blotchy oak-like grain, often different, howerer, in colour. The timber is hard and heary, and that of some kinds very tough.

Principal uses.-For shingles, and at one time largely for staves, though far less at the present time. It is excellent for ornamental turnery work generally, and for cabinet work, for which it is generally used in veneers. Then we have such uses as veneer for the backs of brushes, and for what is known as Tunbridge ware. For all the above uses (except shingles and staves), I am of opinion that there might be created for various she-oak timbers a very large demand in Great Britain and the continent of Europe. Some of them, e.g., river oak and swamp oak, ar'e much prized for bullockyolres, as their timber is comparatively light and tough, and the bolts do not work loose. She-oak timber makes excellent mauls, tool-handles, and very ornamental walking-sticks, good screws of hand-screws; in fact, one species or another may be put to very many useful purposes.

Distribution.-In most parts of the Colony.

Quantity available.-Very large. 
7. BLACK BEAN, MYALL, \&c.

Black Bean (Castanospermum australe, A. Cunn.)

(An illustrated article descriptive of this timber will be found in the Agricultural Gazette for January, 1894).

Name.--That of black bean is given to this timber, because of its darkness-darker than walnut. The tree bears large pods or "beans."

Other local names.-Moreton Bay chestnut. The tree was first discovered near Moreton Bay (the modern Brisbane). The contents of the pods the tree bears are very large seeds, resembling in size, and in 'general appearance, horse chestnuts.

Characteristics. - In appearance strongly resembling walnut. It. is darkcoloured, fine-grained, and takes a good polish. Very few woods can bo dressed with greater facility. It shrinks in drying, though not excessively so, and it is well worthy of any attention that may be given it as regards seasoning. It is of a greasy nature, and will not readily take glue. It is tough and durable. Showy figured specimens are not uncommon.

Principal uscs. - These can be best stated by remarking that black bean is the usual substitute for walnut in this Colony. It is increasingly coming into use for furniture and cabinet-making.

Distribution.-Northern rivers (Clarence to Tweed).

Quantity available.-Fairly abundant, in spite of the fact that stockowners have long waged war against it, because the "beans," if eaten by cattle and horses, produce acute indigestion, and even death.

\section{Myall, Brigalow, \&c. (Acacia of various species).}

We have a number of intensely hard, heavy, dark-coloured woods, which smell more or less of violets. They are used chiefly for turnery work. The trees attain no great size (say 30 or 40 feet) with a trunk-diameter of 12 to 18 inches. They are mostly found in the drier parts of the Colony, and are plentiful. Considerable railway freights add to their cost, but not to a prohibitive extent, as these timbers are usually used for small articles, such as mallets (presentation and otherwise), turned cups and boxes, rulers, draughtsmen, chessmen, and the better class of turned work generally.

A quantity of this timber has been recently shipped to England, having been selected by the Ordnance Department for the manufacture of spokes for gun carriages.

True myall (Acacia pendula), brigalow (Acacia harpophylla), jarran (Acacia homalophylla), are the principal timbers of the above class. There are others, and the quantity available will satisfy any demand ever likely to be made upon them.

\section{Blackwood (Acacia melanoxyon, R. Br.)}

This is a valuable and well-known timber, which is used for furniture carriage-building, and many other purposes. I have shown (see an article on the subject in the Agricultural Gazette for March, 1894), that this tree is more widely diffused in New South Wales than is usually supposed, but in most of the localities-particularly in the ranges near the Victorian border; the tree is so distant from markets, as to be only arailable for use in the districts in which it is found. It is much more abundant and readily available in the colonies of Tasmania and Victoria, so that I need not dwell further upon it in a pamphlet devoted to New South Wales: timbers. My 
readers who desire further information are invited to peruse the article above referred to. Closely resembling the blackwood in appearance and properties is the mountain hickory (Acacia penninervis, Sieb.), which is abundant in many parts of the southern districts. I draw attention to it because it is a valuable timber, but it has a formidable and perhaps irresistible competitor in Tasmanian blackwood.

\section{MISCELLANEOUS BRUSH TIMBERS.}

\section{(a) Tulipwood (Harpullia pendula, Planch.)}

This is one of the handsomest of Australian woods. It is tough, closegrained, and beautifully marked with different shades from black to yellow, and, therefore, much esteemed for cabinet-work. Billiard-tables have been made of it, while it has been used as panels in doors and dadoes, and with selected pieces the effect may be described as gorgeous. It resembles olivewood somewhat in general appearance. It is a very durable timber. It is found in the northern brush forests, and is moderately plentiful.

\section{(b) Muskwood (Olearia argophylla, F. v. M.)}

The root-stock of this tree, found in the southern mountain districts, is very gnarled, and, when cut into, the timber is seen to be full of birds' eyes and crinkly folds, reminding one somewhat of bird's eye maple. It requires the most careful seasoning, otherwise it warps and twists badly. The wood should be cut into veneers, which are so beauliful that they are worthy of some effort being taken in regard to them.

\section{(c) Flindosa, or Cudgerie (Flindersia australis, R. Br.)}

A large tree, found in the northern districts and extending as far south as Wyong. It is a pale-coloured, generally useful wood, which shrinks but little in drying. It is hard, and hence sometimes objected to on that score. A recent special use is for railway keys. It is fairly plentiful. It is often used as a substitute for colonial beech, which it resembles a good deal in outward appearance.

\section{(d) Native Teak (Flindersia Bennettiana, F. v. M.)}

A large tree, chiefly to be found in the brush forests of the Richmond and Tweed. It is heavy, hard, and difficult to work. Durable in and out of the ground. Does not discolour water, hence used for well-slabbing. Highly inflammable when green, but far less so when dry. Recommended for gearing wheels, which do not splinter with the pressure of one tooth against another. Fairly plentiful.

\section{(e) Blue-berry Ash (Elcoocarpus).}

Species of Elceocarpus, which variously go under the names of "blue-berry ash," "pigeon-berry ash," and sometimes " mountain ash" and " whitewood," are found in the coast districts, and produce a nice looking, white, tough timber. On the Richmond River the trees, both in bark and timber, resemble the cudgerie somewhat. "Blue-berry ash" is very good for bed-room furniture, staves, oars. It is not a particularly abundant timber, but it is so bright-looking and easily worked as to be always in demand. I prefer it to all other colonial timbers for large picture frames, but the supply in the Sydney market is so fitful that I frequently have to be content with beech, which is a duller-looking timber. 
(f) Maiden's Blush (Echinocarpus 'australis, Benth.)

A soft, durable brush timber, useful for turnery and ordinary carpentry purposes. It is of a delicate rosy colour when freshly cut, but this fades into a brownish colour. It is found principally on the northern rivers, and may be had in fair quantity. This and coachwood may be taken as types of our useful non-figured brush timbers, a little harder than pine, and used for many miscellaneous purposes.

\section{(g) Red Ash (Alphitonia excelsa, Reissek.)}

Although not one of our commonest timbers, I draw attention to this timber because of the peculiarity of its colouring. When a $\log$ is first cut, it resembles ordinary ash in colour, and for some time no change is perceptible. After a time it gradually assumes a reddish colour, which deepens for two or three years, by which time it has assumed a fiery red appearance. This colouration is superficial, and may be removed by the plane, but its depth of tint again returns in process of time. It is very ornamental.

\section{(h) Saxifrageæ.}

This natural order contains a large number of trees, some of good size. Their characteristics are absence of figure (they, therefore, could not be used for ornamental work), freedom in working, little tendency to split in seasoning. 'They comprise useful timbers, which are chiefly used locally, and, as their qualities become better known, they will have extended use in the Colony. I do not anticipate that they will be in much demand for export purposes, except for such special objects as gun-stocks.

They inclnde such timbers as "corkwood" (Ackama Muelleri), "coachwood" (Oeratopetalum apetalum), a timber which I am assured by a leading coach-builder, is one of the most valuable timbers in the Colony for coachbuilding. 


\section{TIMBERS FOR SPECIAL PURPOSES.}

THIs list of special uses of our principal native timbers does not, of course, profess to be exhaustive. It may, however, be suggestive. It will be added to from time to time.

Bee-boxes.

Cedar.

Beech.

Bending Timbers.

Spotted gum.

Blackwood.

Cedar.

Boat-building.

Boat-knees.

Prickly tea-tree.

White tea-tree and other tea-trees.

Water gum.

Red honeysuckle.

White honeysuckle.

Mangrove.

Boring-rods (for artesian wells). Spotted gum.

Tallow-wood.

\section{Bridge-decking.}

Red mahogany.

White mahogany.

Blackbutt.

Spotted gum.

Murray red gum.

Rosewood.

Broom-handles.

Beech.

Blue-berry ash.

Spotted gum.

Tallow-wood.

River oak.

Bullock-yotes.

Swamp oak.

Brush box.

Hickory or Black wattle.

Mangrove.

White honeysuckle.
Butter-boxes.

Colonial pine.

Silky oak.

Butter-kegs.

Red silky oak.

\section{Carriage-building.}

(See my article on this subject in the Agricultural Gazette for August, 1894, page 549).

Coachwood.

Red cedar.

Rosewood.

Plumwood.

Beech.

Brown or bully beech.

Colonial pine.

Blackwood and mountain hickory.

White holly.

\section{Carving.}

Cheesewood.

Coachwood.

White teak.

Native orange.

Scrub hickory.

Soapwood.

Corkwood.

Long Jack

Rosewood.

Pluniwood.

Black bean.

Cedar.

Beech.

Brown pine.

Colonial pine.

Native guava.

Celastrus dispermus. Both this and the preceding are beautiful white woods. The Celastrus has no common name.

There are probably very many other useful carving timbors. 
Cedar.

Beech.

Colonial pine.

Cypress pine.

Blue-berry ash.

Sassafras.

Cobra-resisting timbers.

Turpentine.

Tallow-wood,

Red mahogany.

Ironbark.

Priekly tea-tree and other tea-trees.

Brown pine.

Teak.

Ceilings.

Tea-tree.

Cricket-bats.

Black pencil cedar.

Silky oak.

$$
\text { Dairy utensits. }
$$

Red silky oak.

Red cedar.

\section{Doors.}

Pine.

\section{Engraving.}

(Bold outlines only.)

Cheesewood (softer and tougher than Turkey box).

Native cherry.

Wild lemon.

Brush ironbark, and perhaps other timbers belonging to the Rutacece and Sapindaceer.

\section{Felloes.}

Blue gum (sometimes called woolly butt).

Grey gum.

Beech.

$$
\text { Floats of Mill Wheels. }
$$

Mountain ash.

Tallow-wood.

\section{Flooring.}

Beech.

Colonial pine.

Sassafras.

\section{Fheel.}

Pine-knots (Colonial or hoop pine). Cypress pine.

Teak.

Box.

Ironbark.

She-oak.

Honeysuckle.

Red cedar.

Rosewood.

Red bean.

Onion-wood.

Black bean.

White ash.

Tulipwood.

Cherry.

Gun stocks.

Furniture.

Blackwood.

Mountain hickory.

Coachwood.

Maiden's blush.

Many wattles.

Spotted gum.

Mountain ash.

Water gum.

Handles (axe).

Blackwood.

Pigeon-berry ash.

Native cherry.

Brush-box.

Water gum.

Swamp oak.

Grey box.

Spotted gum.

House-blocks (Wooden piers or piles).

Rosewood.

Cypress pine.

Grey gum.

Murray red gum.

Forest red gum.

Red mahogany.

Ironbark.

Lining-boards.

Same as "Ceilings:" 


Water gum.
Brush-box.
Pigeon-berry or native beech.
Plumwood.
Tulipwood.
Mangrove.
Swamp oak.
Grey box.
Water gum.
Rosewood.
Red bean.
Apple.
Spotted gum.
Tronbark.
Grey box.
Blue-berry ash.

Tallow-wood.

Paving.

Blackbutt.

Mahogany.

Blue gum.

Grey gum.

White mahogany.

Spotted gum.

Murray red gum.

Bloodwood.

Turpentine.

Black bean.

Piano-frames.

Red bean.

Rosewood.

Beech.

$$
\text { Picture-frames. }
$$

Blue-berry ash.

White boneysuckle.

Blackwood.

Turpentine.

$$
\text { Piles. }
$$

Brown pine.

Needlewood.

$$
\text { Pipes (tobacco). }
$$

Myall.

Brush-box.
Plumwood.
Blackwood.

Irombark.

Red box.

White mahogany.

Tallow-wood.

Red gum.

Grey gum.

Red mahogany.

Bloodwood.

Turpentine.

\section{Posts.}

\section{Railway Keys.}

Cedar.

Flindosa.

İronbark.

Railway Sleepers.

Grey gum.

Murray red gum.

Railway Waggon-building.

Ironbark.

Grey box.

Tallow-wood.

Blackbutt.

Rosewood.

Screws.

Swamp oak.

Water gum.

Plumwood.

Native cherry.

Grey box.

$$
\text { Jaws of Screws. }
$$

Brush-box.

Shafts and Poles.

Spotted gum.

Mountain ash.

Ironbark.

Grey box.

Blackwood.

Mountain hickory.

Sheaves and Blocks.

Water gum.

Beech.

Blackwood.

Mountain hickory.

Forest oak.

Shingles.

Grey gum.

Red mahogany. 
Apple.

Ironbark.

Spotted gum.

Blackbutt

\section{Staves (for casks).}

(See my article, entitled "Colonial Timbers for Wine Casks," in the Agrioultural Qazette for June, 1894).

Silky oak.

Red silky oak.

Black wattle.

Silver wattle.

Mountain hickory.

White ash.

Blackwood.

Red ash.

Ironwood.

Blue-berry ash.

Rosewood.

Coachwood.

Ironbark.

Swingle-trees.

Mountain ash.

Spotted gum.

Blue or flooded gum.

Tram-rails.

Brush box (north coast).

Spotted gum (south coast).

\section{Turnery.}

She-oak, especially forest oak.

Rosewood.

Blackwood.

Black bean.

Tulip and many other timbers.

Beech.

Vats.

\section{Veneers.}

She-oak.

Tulip.

Figured black bean.

Musk.

Honeysuckie.

Red silky oak.
Walking Sticks.

(See my article on the subject in the Agricultural Gazette for March, 1894).

(a) Whole plant:-

Tea-trees.

Dwarf palms (Mitchinbills, Walking-stick palms).

Native cherry.

Oaks.

Honeysuckles.

Wattles.

Brush box.

Sweet root, and very many others.

(b) Cut out of solid :-

Blackwood.

White honeysuckle.

Forest oak.

Tulip.

Cabbage palm, and very many others.

\section{Weather-boards}

Tallow-wood.

Red mahogany.

Teak.

Well-slabs.

White-ant resisting Timber's.

Cypress pine.

Brown pine.

Red mahogany.

Wine-casks (see also "Staves.")

White ash.

Blackbutt (fissile).

Beech.

Silky oak.

Rosewood.

Silver wattle.

Black wattle.

Wire-mattress Frames.

Colonial Pine.

Rosewood. 



\section{INDEX.}

Acacia harpophylla ................... $\quad \mathbf{2 3}^{\mathbf{2 3}}$

, homalophylla........ 23

" melanoxylon ...................... 23

pendula ........................... 23

penninervis ................... 24

Ackama Muelleri...................... 25

Alphitonia excelsa.................... $\quad 25$

Araucaria Cunninghamii............... 19

Banksia integrifolia ................... 22

Banksia serrata ......................... 22

Bee-boxes .............................. 26

Beefwood .............................. 21

Belar ................................... 22

Bending timbers ...................... 26

Black bean ............................... 23

Blackbutt ............................. 10

Black oak .............................

Black pine ............................... 20

Black turpentine........................ 16

Blackwood ............................. 23

Bloodwood ............................... 15

Blue-berry ash ........................ 24

Blue gum ............................ 14

Boat=building............................ 26

Boat knees ..............................., 26

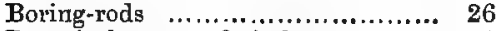

Botanical names of timbers ... ....... 4

Botany oak............................ 22

Bridge-decking ......................... 26

Brigalow............................... 23

Broad-leaved ironbark ................ 7-8

Broom handles ......................... 26

Brown pine ............................ 20

Brush-box ........................... 16-17

Bull oak ............................. 22

Bullock yokes.......................... 26

Butter-boxes .........................., 26

Butter-kegs $\ldots \ldots \ldots \ldots \ldots \ldots \ldots \ldots \ldots \ldots, 26$

Callitris calcarata.................... 20

, coltmellaris ................ 20

, Macleayana..................... 20

$"$ verrucosa ........................ 20

Carrisge-building ...................... 26

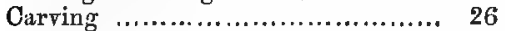

Castanospermum australe............. 23

Casuarina ........................... 22

Cedar .................................. 17

Cedrela australis ....................... 17

Ceilings ............................... 27

Cerstopetalum apetalum .............. 2.5

Coachl wood ................................. 25

Cubra-resisting timbers.................... 27

Cog-wbeels ............................... 2

Colonial or Moreton Bay pine........ 19
PAGE.

Common names of timbers

Corkwood ........................... 25

Cricket bats ............................ 27

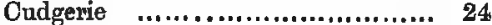

Cyprese pine ........................... 1-20

Duiry utensils ........................., 27

Doora ..................................... 27

Dysoxylon fraserianum ................. 18

,; Muellewi ................. 18

Echimosarpus australis................. 25

Elcocarpus ............................. 24

Fingraving .............................. 27

Eucabyptus acmenoides.................. 10

corymbosa ................ 15

crebra ...... ........... 7-8

hemiphtoia................ 12

longifolia .................. 15

maculata ................. 11

microcorys ............... 11

paniculata .............. 7-9

pilularis ................. 10

resinifera ................. 12

rostrata ................. 13

saligna ................... 14

siderophloia ............... 7-8

sideroxylan ............. 7-9

tereticornis .............. 14

Export timbers ...................... 2

Felloes................................... 27

Flindersia australis ................... 24,

Bennettiana................. 24

Flindosa

Floats of mill wheels ............... 27

Flooring ............................... 27

Forest oak ............................ 22

, red gum ........................ 14

Forest wealth of the Colony ......... I

Frenela ................................... 20

Fuel .................................... 27

Furniture ............................ 27

Gmelina Leichhardtii ................ 19

Grevillea robusta ....................... 21

Grey box................................ 12

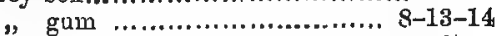

Gun-tocks ............................. 27

Hakea leucopter 4 ..................... 22

Handles, axe ........................... 27

tool ........................ 27

Hardwoods, pale ....................... 10 


\begin{tabular}{|c|c|c|}
\hline & & PAGE. \\
\hline Hardwoods, $r$ & 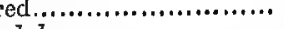 & \\
\hline Harpullia per & ndula.......................... & 24 \\
\hline Honejsuckle & 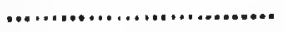 & 22 \\
\hline House-blocks & 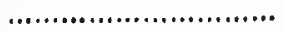 & 27 \\
\hline
\end{tabular}

Lining boards......................... 27

Mahogany, red ........

white ...................... 10

Maiden's blush ......................... 25

Mallets ................................., 28

Mauls ................................., 28

Merits of timbers ..................... $\mathbf{2}$

Moreton Bay chestnut .................. 23

, pine ................... 19

Mountain hickory.................... 24

Mugga ..................................

Murray or white pine ............... 20

, red gum ..................... 13

Muskwood .............................. 24

Myall ................................. 23

Narrow-leaved ironbark ............. 7-8

Native teak ............................ 24,

Naves ..................................... 28

Needlewood........................ .622

Oars........................................ 28

Olearia argophylla .................... 24

Onion wood ............................. 18

Orites excelsa............................. 21

Owenia cepiodora ..................... 13

Pale hardwoods .. ....................... 10

Paving................................... 28

Piano frames ........................... 28

Picture frames .......................... 28

Piles ..................................... 28

Pipes (tobacco) ......................... 28

Planes.................................... 28

Podocarpus elata ........................ 20

Poste ................................... 28

Processes of seasoning ................. 4

Proper season for felling timbers...... 4

Railway keys .......................... 28

Railway sleeper's ....................... 28

Red ash waggon-building ..................................... 28

,, bean ................................. 18

" cedar .............................. 17

, gum, forest........................ 13
PAGE.

Red gum, Murray ................... 13

" hardwoods......................... 12

, ironbark ........................... 9

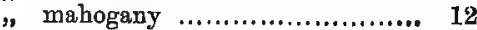

" pine.................................. 20

", silky oar............................. 21

River oak .............................. 22

Rosewood ............................. 18

Screws.................................. 28

Seasoned Colonial timbers ............ 3

Seasoning processes ................... 4

Shafts and poles.......................... 28

Sheaves and blocks......................., 28

She-oak ................................., 22

Shingles .................................., 28

Silky oak................................., 21

Special purposes for timbers ......... 26

Spokes...................................... 29

Spotted gum ........................... 11

Staves (for casks) ...................... 29

Stenocarpus salignus.................... 21

Substitution of inferior kinds of timber ............................. 2

Supply of seasoned Colonial timbers $\mathbf{3}$

Swamp oak............................. 22

Swingle-trees .............................., 29

Sydnoy blue gum ..................... 14

Synearpia laurifolia.................... 16

Tallow-wood ........................., 11

Tram-rails ................................. 29

Tristania conferta ...................., 17

True myall.............................. 23

Tulipwood ........................... 24

Turnery ................................. 29

Turpentine ............................ 16

Vats....................................., 29

Veneers ............................... 29

Walking-sticks ....................... 29

Weatherboards .......................... 29

Well slabs ............................. 29

White-ant resisting timbers............ 29

White beech ........................... 19

, or grey ironbark................. 8

") mahogany ....................... 10

"pine................................ 19

Wine-casks.............................. 29

Wire-mattress frames ................. 29

Wooden piers or piles .................. 27

Woollybutt ......................14-15-17

Yarran ............................... 23 





